\title{
Safety of potential breast milk exposure to IFN- $\beta$ or glatiramer acetate
}

\section{One-year infant outcomes} Andrea Ines Ciplea, Annette Langer-Gould, MD, PhD, Anna Stahl, MD, Sandra Thiel, PhD,
Annette Queisser-Wahrendorf, MD, Ralf Gold, MD, and Kerstin Hellwig, MD

Neurol Neuroimmunol Neuroinflamm 2020;7:e757. doi:10.1212/NXI.0000000000000757

\section{Abstract}

\section{Objective}

To determine whether potential breast milk exposure to interferon-beta (IFN- $\beta$ ) or glatiramer acetate (GA) is safe for the infant.

\section{Methods}

We identified 74 infants born to 69 women with MS who breastfed under IFN- $\beta$ ( $n=39)$, GA $(n=34)$, or both $(n=1)$. Women had been enrolled into the German Multiple Sclerosis and Pregnancy Registry during pregnancy. Data were obtained from standardized, telephoneadministered questionnaires completed by the mother during pregnancy and at $1,3,6$, and 12 months postpartum and the infant's take-home medical record.

\section{Results}

The median duration of exposed breastfeeding was 8.5 months (wide interquartile range: 4.9-12.7 months). Physical growth curves during the first year of life were consistent with national, sex-specific growth curves. Median body measurements were consistent with national medians. Most children $(n=71,96 \%)$ had normal motor and language development. Gross motor delay was reported in 3 children, of whom 1 remained delayed at last follow-up (3.9 years old) and 2 were normal by 0.9 and 4.1 years old. The proportion of children hospitalized at least once (girls $n=2,7 \%$, and boys $n=6,14 \%$ ) and the proportion of children with at least one episode of systemic antibiotic use during the first year of life (girls $n=7,23 \%$, and boys $n=8,18 \%$ ) are consistent with national averages.

\section{Conclusion}

Potential breast milk exposure to IFN- $\beta$ or GA did not increase the risk of common adverse infant outcomes in the first year of life. Taken together with the benefits of breastfeeding and low biological plausibility of risk, women with MS who wish to resume IFN- $\beta$ or GA postpartum can be encouraged to breastfeed.

\author{
Correspondence \\ Dr. Hellwig \\ k.hellwig@klinikum-bochum.de
}




\section{Glossary}

CA = congenital anomaly; DMT = disease-modifying therapy; FTT = failure to thrive; IFN- $\beta=$ interferon-beta; GA = glatiramer acetate; RID = relative infant dose.

Exclusive breastfeeding is recommended for at least the first 6 months of life by the World Health Organization due to its multiple infant and maternal health benefits. ${ }^{1}$ Before the introduction of MS disease-modifying therapies (DMTs), breastfeeding rates among women with MS were similar to their reference populations ${ }^{2}$ but dropped significantly thereafter. ${ }^{3,4}$ Women with MS feared an increased risk of relapse in the early postpartum period and were counseled to choose between breastfeeding and resuming DMTs due to the lack of safety data. ${ }^{5}$

Two decades later, data on breastfeeding under DMTs are scarce with only few case reports, even for DMTs with low biological plausibility of adverse infant effects (interferon-beta $[$ IFN- $\beta]$ or glatiramer acetate $[\mathrm{GA}]) .^{6-8}$ IFN- $\beta$ and GA are large-molecule self-injectables, and both are unlikely to be absorbed by the child to a significant amount. ${ }^{9,10}$ Investigating the safety of these DMTs during breastfeeding is important because it is plausible that the health risks of withholding breastfeeding may outweigh any theoretical risks of DMT exposure through breast milk. In this prospective cohort study, we aimed to assess a wide array of early life outcomes in children who were breastfed while their mothers took IFN- $\beta$ or GA.

\section{Methods}

\section{Study population}

Women who enrolled between 2011 and March 2018 were selected from the German Multiple Sclerosis and Pregnancy Registry (DMSKW) ${ }^{11}$ Women are recruited to the registry by physicians, nurses, or advertisements. Inclusion criteria were enrollment in the DMSKW during pregnancy, live birth, at least 1 day of IFN- $\beta$ or GA use while breastfeeding, and a follow-up of at least 1 year. We collect detailed information on medical history, MS activity, medications, pregnancy complications and outcomes, breastfeeding, child development, and health from a standardized telephoneadministered questionnaire in each trimester after enrollment, 1, 3, 6, and 12 months postpartum and annually thereafter up to age 6 years.

The mothers are asked to reference the child's take-home medical record (yellow booklet) ${ }^{12}$ to provide information on weight, length, head circumference, selected developmental milestones (gross and fine motor and cognition/language/ social skills), chronic conditions, and documented anomalies. Every child in Germany receives a yellow booklet at birth in addition to an immunization booklet where the pediatrician documents these outcomes during well-baby visits at age 1 week and months $1,4,7,12,24,36,48$, and 64 . The booklet remains with the child's caregiver and a copy with the pediatrician. The majority (97.2\%) of children participate in all checkups from birth to age 5 years. ${ }^{13}$ Photocopies of the yellow booklets were obtained for verification in all cases with reports of developmental delay or other abnormalities. For 35 $(50 \%)$ of those where no development delays were reported, copies of the booklet were provided confirming the statement of the mother. Where a copy of the booklet was not provided, we used the data reported during the interviews. Congenital anomalies (CAs) were rated and classified in accordance with the guidelines of EUROCAT (European surveillance of CAs) by a teratologist (A.Q.-W.).

\section{Standard protocol approvals, registrations, and patient consents}

The DMSKW is approved by the Institutional Review Board of the Ruhr-University Bochum (18-6474-BR). All women gave informed consent.

\section{Exposure}

Breastfeeding under IFN- $\beta$ or GA was defined as breastfeeding (exclusively or nonexclusively) for at least 1 day while being on IFN- $\beta$ or GA treatment. Exclusive breastfeeding was defined as breastfeeding for at least 2 months without supplemental feedings. ${ }^{4}$ Nonexclusive breastfeeding was defined as breastfeeding but with replacement of a meal within the first 2 months postpartum. ${ }^{4}$ Infants who were DMT exposed during the 3 rd trimester or longer (i.e., 3rd, 2 nd and $3 r d$, or continuously during pregnancy) and breastfed were considered exposed via breast milk directly from the first day of life.

For the German reference groups for infant outcomes, data on breastfeeding were lacking. No stratified analyses for breastfed infants were provided.

\section{Outcomes}

Preterm birth (yes/no) was defined as birth before completed 37th week of gestation. Outcomes included weight (in grams), length/height (in centimeters), and head circumference (in centimeters) as continuous variables at birth and at the 7th and 12th months' checkups. Physical growth delay was defined as falling below the 3 rd percentile on at least 1 body measurement (yes/no) on at least 1 checkup (failure to thrive $[\mathrm{FTT}]$ ). Development delays (yes/no) were defined as development delays reported by the mother during the telephone interviews and confirmed by the treating pediatrician (yellow booklet). Hospitalization within the first year of life was defined as overnight admission (yes/no) including hospitalizations directly after delivery (yes/no). Antibiotic use was defined as antibiotic treatment used independently of 
route of administration (yes/no). For infants with at least 1 antibiotic use in the first year, only systemic treatments were included, as in the reference population. ${ }^{14}$ Hospitalizations and antibiotic uses were reported by the mother during the interviews.

\section{Statistical analysis}

To identify potential FTT, we compared the median weight, length, and head circumference-separately of the total cohort and the 3rd trimester or longer cohort-with age- and sex-specific values obtained from the general German pediatric population. ${ }^{15}$ Preterm births were excluded from the growth analyses, as was done in the reference population. ${ }^{15}$ The percentages of infants with at least 1 hospitalization or 1 systemic antibiotic treatment in the first year of life or developmental delay after being exposed to IFN- $\beta$ or GA for at least 1 day during breastfeeding were compared with German pediatric populations (for hospitalizations and antibiotic use separated by sex as in the reference populations). ${ }^{14,16,17}$

A 2-sided $t$ test was used to compare mean values and SDs, the Wilcoxon rank-sum test was used for nonnormally distributed variables, and the $\chi^{2} /$ Fisher test was used for differences in categorical variables. Statistical significance was set at $p<0.05$.

We used multivariate logistic regression to estimate the crude OR of 3rd trimester or longer exposure to IFN- $\beta /$ GA during pregnancy (yes/no) with 95\% CIs for the following outcomes: hospitalization in the first year of life, antibiotic use in the first year of life, and FTT. Models were adjusted individually and mutually for exclusive breastfeeding (yes/no), duration of breastfeeding under IFN- $\beta /$ GA (days), and mother's age at the time of conception (years). Logistic regression of the 3rd trimester or longer was used also for the outcomes preterm birth (adjusted for mother's age at the time of conception [years]) and hospitalization directly after delivery (adjusted for mother's age at the time of conception [years] and preterm birth [yes/no]). We included and retained predefined known and biologically plausible confounders in our models.

Analyses were conducted with the total cohort (IFN- $\beta$ - and GA-exposed infants together) and separately stratified into 2 groups for type of drug exposure. FTT, antibiotic treatments, and hospitalizations occurring before IFN- $\beta /$ GA breast milk exposure were not included in the analyses. There were no developmental delays detected before breast milk exposure.

Cases with missing data were excluded only for the respective analysis. All statistical analyses were conducted using SAS version 9.4 (SAS Institute, Cary, NC).

\section{Data availability}

No deidentified patient data will be shared. No related studyrelated documents will be shared. Reasonable requests from any qualified investigator for anonymized data will be considered by the corresponding author.

\section{Results}

We identified 73 pregnancies resulting in 74 live births among 69 women who reported breastfeeding while taking IFN- $\beta$ or GA with at least 1-year follow-up from the 1,702 prospectively captured pregnancies in the DMSKW between 2011 and March 2018. Median postpartum follow-up was 21.6 months (interquartile range 14.4-27.6 months). General characteristics of the cohort are shown in table 1.

The majority of infants $(n=72,97 \%)$ had some pregnancy exposure to DMTs. Notably, 17 (23\%) infants were exposed to IFN- $\beta(n=12)$ or GA $(n=5)$ uninterrupted throughout the entire pregnancy. Most infants were exposed to DMTs during the 1 st trimester $(\mathrm{n}=72,97 \%)$, after which $73 \%(\mathrm{n}=$ 54) discontinued DMTs (median 33, range 0-140 days after the last menstrual period). Treatment was restarted during the 2 nd or 3 rd trimester in 9 women (IFN- $\beta[\mathrm{n}=3]$ and GA $[\mathrm{n}=6]$, including 1 twin pregnancy), only one of whom resumed because of an MS relapse.

The median duration of IFN- $\beta /$ GA-exposed breastfeeding was 8.5 months, with a very wide range of $0.50-28.5$ months. The median duration of total breastfeeding was 10.8 months (range 1.1-28.8 months), with most infants $(\mathrm{n}=57,77 \%)$ being breastfed exclusively for a median duration of 5.9 months (range 2.1-14.1 months). Following delivery, INF- $\beta$ /GA was continued uninterrupted in all 26 cases exposed to DMTs during the 3rd trimester or longer. Among the other 48 infants, DMT was resumed with a median of 1.0 month (range 0.0-9.2 months) postpartum (GA: $n=23$, IFN- $\beta: \mathrm{n}=25$ ).

Thirty-nine (53\%) infants were exposed to IFN- $\beta$ during lactation, $34(46 \%)$ to GA, and 1 to both (table 1$)$. Most women $(n=63)$ continued their therapy from before pregnancy during breastfeeding. Those who were on no or a different DMT before pregnancy switched as follows: dimethyl fumarate, 3 switched to IFN- $\beta$ and 1 to GA; fingolimod, 2 switched to GA; and no DMT, 2 to switched IFN- $\beta$ and 1 to GA.

\section{Pregnancy and neonatal outcomes}

Twenty-five of 74 (34\%) infants were born by cesarean section. Mean gestational week at birth was 39.3 (SD, 1.75). Seven infants (9\%) were born premature, including 1 pair of twins. All premature births were exposed to DMTs during pregnancy ( 4 during the 1st trimester and 3 whose mothers restarted treatment during the 3 rd trimester) compared with 97\% (42 during the 1st trimester, 6 whose mothers restarted treatment during the $3 \mathrm{rd}$ trimester, and 17 with continuous pregnancy exposure during pregnancy) of full-term births ( $p$ $=1.00)$. IFN- $\beta / \mathrm{GA}$ exposure during the $3 \mathrm{rd}$ trimester or longer was not associated with an increased risk for preterm birth compared with those with no or early pregnancy DMT exposure only in crude (OR 1.44, 95\% CI 0.30-7.0, $p=0.65$ ) or adjusted (OR 1.01, 95\% CI 0.17-6.27, $p=0.99$ ) models. 
Table 1 Characteristics of the study population

\begin{tabular}{|c|c|}
\hline Characteristics & Values \\
\hline & Mean (SD) \\
\hline Age at conception, $y$ & $33.5(3.36)$ \\
\hline Education & No. (\%) \\
\hline Completed university studies ${ }^{a}$ & $48(66)$ \\
\hline Completed vocational training $^{a}$ & $22(30)$ \\
\hline No completed vocational training ${ }^{a}$ & $2(3)$ \\
\hline $\begin{array}{l}\text { Body mass index at the } \\
\text { beginning of pregnancy }\end{array}$ & $24.4(5.06)$ \\
\hline \multirow[t]{2}{*}{ Disease duration at conception, y } & $5.98(5.03)$ \\
\hline & Median (range) \\
\hline $\begin{array}{l}\text { No. of relapses in the } 2 y \\
\text { preceding conception }\end{array}$ & $0(0-5)$ \\
\hline $\begin{array}{l}\text { Gestational week at } \\
\text { entry into the cohort }\end{array}$ & $10.71(1.00-39.71)$ \\
\hline DMT exposure & $\begin{array}{l}\text { No. (\%); median } \\
\text { (range) }\end{array}$ \\
\hline \multicolumn{2}{|l|}{ At conception } \\
\hline IFN- $\beta$ & $35(47)$ \\
\hline $\mathrm{GA}^{\mathrm{b}}$ & $30(41)$ \\
\hline Dimethyl fumarate & $4(5)$ \\
\hline Fingolimod & $2(3)$ \\
\hline No treatment & $3(4)$ \\
\hline \multicolumn{2}{|l|}{ During pregnancy } \\
\hline First trimester only & $46(62)$ \\
\hline $\begin{array}{l}\text { Resumed during the } \\
\text { 2nd/3rd trimester }\end{array}$ & $9(12)$ \\
\hline Entire pregnancy & $17(23)$ \\
\hline None (breastfeeding exposure only) & $2(3)$ \\
\hline \multicolumn{2}{|l|}{ During lactation } \\
\hline $\begin{array}{l}\text { IFN- } \beta \text {; duration of exposed } \\
\text { breastfeeding (mo) }\end{array}$ & $39(53) ; 9.2(1.6-28.5)$ \\
\hline IFN $\beta-1$ a SC $3 \times / w k$ & $15(21)$ \\
\hline IFN $\beta$-1a IM weekly & $12(16)$ \\
\hline IFN $\beta$-1b SC every other day & $8(11)$ \\
\hline Peginterferon $\beta$-1a SC every 2 wk & $1(1)$ \\
\hline IFN- $\beta$ not specified & $3(4)$ \\
\hline $\begin{array}{l}\text { GA daily; duration of exposed } \\
\text { breastfeeding (mo) }\end{array}$ & $34(46) ; 7.8(0.5-19.9)$ \\
\hline GA daily and IFN $\beta-1$ b SC every other day & $1(1)$ \\
\hline
\end{tabular}

Abbreviations: DMT = disease-modifying therapy; GA = glatiramer acetate; IFN- $\beta=$ interferon-beta.

a Based on the number of cases with available data.

b Twin pregnancy.
Seven infants (9\%) were hospitalized immediately after delivery: 2 for premature birth and the remaining for neonatal infection, hypoglycemia, fever, icterus neonatorum, or hemorrhagic diarrhea. Five were exposed during the 1st trimester only and 2 from the 2nd trimester onward. Exposure to DMTs during the 3rd trimester or longer was not associated with an increased risk of hospitalization immediately after delivery (crude OR $0.72,95 \%$ CI $0.13-3.98, p=$ 0.70 ; adjusted OR $0.41,95 \%$ CI $0.06-3.07, p=0.39)$ compared with no or only 1 st trimester DMT exposure. Three infants had minor CAs: ankyloglossia $(\mathrm{n}=1$, entire pregnancy exposure), undescended testicle $(\mathrm{n}=1)$, and ovarian cyst $(\mathrm{n}=1)$, both 1 st trimester exposure. No major CAs were detected.

\section{One-year infant outcomes}

Median body weight, length, and head circumference of fullterm infants are displayed in the percentiles of the German population at birth and the 7- or 12-month checkup (figure). Seven full-term infants ( 3 girls and 4 boys) fell below the 3 rd percentile on at least 1 body measurement at at least 1 checkup. However, this was not associated with either IFN$\beta /$ GA exposure during breastfeeding or pregnancy (tables 2 and 3 ). Available data on body measurements are shown in table 4.

Four mothers reported development delays in their offspring during the first year, 3 of which were confirmed by the pediatrician. These 3 (4\%) had developmental delays in motor skills noted during checkups at 7 and 12 months. Two children caught up during the follow-up period so that by 12 and 48 months of age their motor skills were normal. One girl was reported as clumsy regarding gross motor skills and still received physiotherapy at 48 months (last follow-up). One report of language delay was not confirmed by the pediatrician. The percentage of developmental delay did not differ from the reference population ( $4 \%$ vs $5.5 \%$ in the reference population, $p=0.59) .{ }^{17}$

Eight infants (11\%) with breast milk DMT exposure were hospitalized in the first year of life. Reasons included infections or fever $(n=5)$, surgical correction of retracted testicle, hypoglycemia, and premature birth. The percentage of infants with at least 1 hospitalization did not differ significantly from the German reference population (girls $7 \%$ vs $14.9 \%, p=$ 0.21 /boys $14 \%$ vs $18.7 \%, p=0.39) .{ }^{16}$ No chronic illnesses were reported.

Fifteen (20\%) infants received at least 1 antibiotic treatment by age 1 year, $14(88 \%)$ as outpatients, and $2(12 \%)$ while hospitalized for pyelonephritis and febrile lymphadenopathy. There were 24 antibiotic treatments in total, 22 (92\%) were administered systemically. Five infants received more than 1 antibiotic treatment. Reasons for outpatient antibiotic use included bronchitis $(\mathrm{n}=8)$, otitis media $(\mathrm{n}=4)$, conjunctivitis $(\mathrm{n}=2)$, and other infections $(\mathrm{n}=8)$. Longer exposure during breastfeeding 

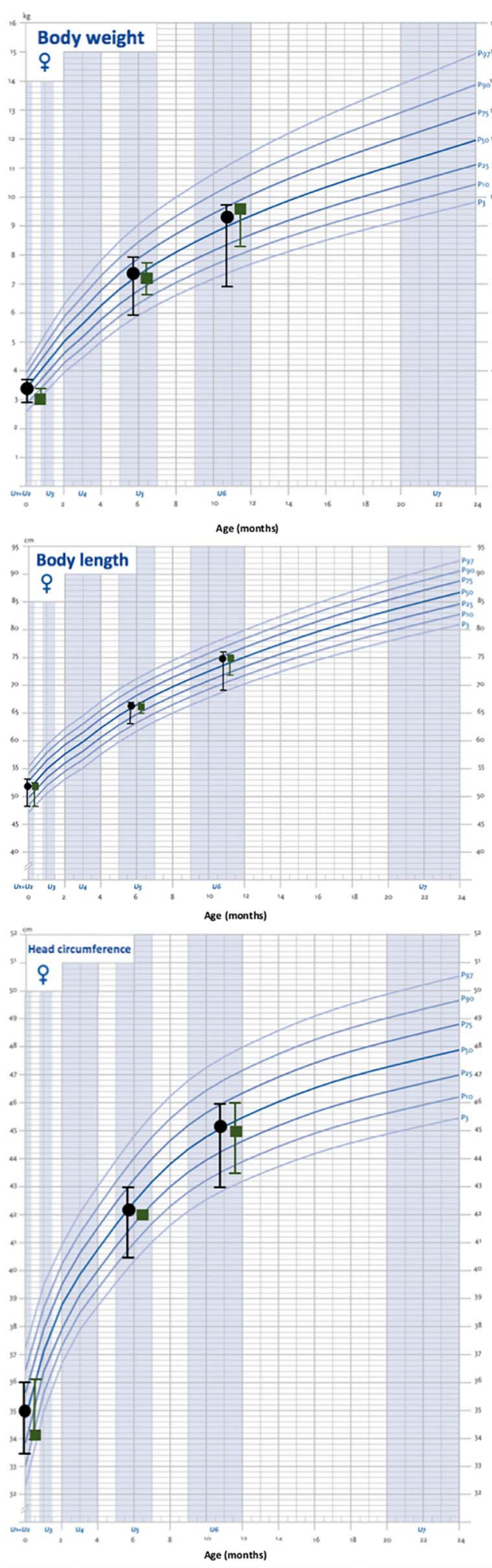
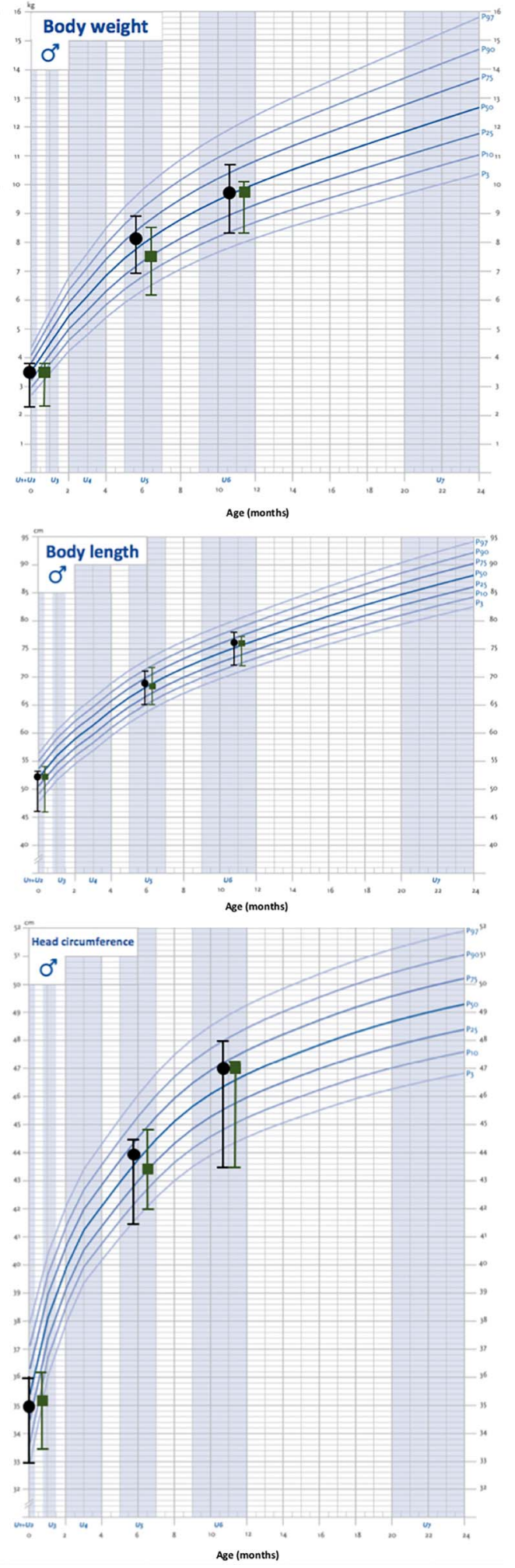

Total cohort $=\mathbf{0}$, infants exposed to DMT during the 3rd trimester or longer $=\mathbf{m}$. Medians with 3rd and 97 th percentiles of body weight, length, and head circumference of the total cohort and infants who were exposed do disease-modifying therapy during the 3rd trimester or longer (separated by sex; excluding preterm infants of < completed 37 th week of gestation) at checkups directly after birth, 7 months of age, and 12 months of age in comparison to the German pediatric population. $^{19}$ was not associated with more antibiotic use. The percentage of infants in our cohort with at least 1 systemic antibiotic treatment (girls $23 \%$ vs $24.8 \%, p=0.85$ /boys $18 \%$ vs $27.2 \%, p=0.18$ ) did not differ significantly from the German population. ${ }^{14}$
Table 2 shows the number of infants with and without adverse outcomes (total cohort and subcohorts stratified for duration of exposure during pregnancy [3 groups]). There were no significant differences between the different exposure groups 
Table 2 One-year infant outcomes and exposure to IFN- $\beta$ or GA during breastfeeding or pregnancy

\begin{tabular}{|c|c|c|c|c|c|c|c|}
\hline & \multirow[b]{2}{*}{$\begin{array}{l}n \\
(\%)\end{array}$} & \multicolumn{2}{|l|}{ IFN- $\beta$ /GA-exposed breastfeeding } & \multicolumn{4}{|c|}{ Pregnancy IFN- $\beta / G A$ exposure } \\
\hline & & $\begin{array}{l}\text { Duration of IFN- } \beta / G A-e x p o s e d \text { breastfeeding } \\
\text { in the 1st year of life, days median (range) }\end{array}$ & $\begin{array}{l}p \\
\text { Value }\end{array}$ & $\begin{array}{l}\text { Continuous, } \\
\text { n (\%) }\end{array}$ & $\begin{array}{l}\text { 2nd and/or 3rd } \\
\text { trimester, } \mathrm{n}(\%)\end{array}$ & $\begin{array}{l}\text { 1st } \\
\text { trimester } \\
\text { only, } \mathrm{n}(\%)\end{array}$ & $\begin{array}{l}p \\
\text { Value }\end{array}$ \\
\hline $\begin{array}{l}\text { Growth } \\
\text { retardation }\end{array}$ & $\begin{array}{l}7 \\
(9)\end{array}$ & $230(110-365)$ & 0.47 & $3(18)$ & $0(0)$ & $4(9)$ & 0.49 \\
\hline $\begin{array}{l}\text { Normal physical } \\
\text { growth }\end{array}$ & $\begin{array}{l}67 \\
(91)\end{array}$ & $245(14-365)$ & & $14(82)$ & $9(100)$ & $42(91)$ & \\
\hline $\begin{array}{l}\text { Development } \\
\text { delay }\end{array}$ & $\begin{array}{l}3 \\
(4)\end{array}$ & $110(82-169)$ & 0.09 & $1(6)$ & $1(11)$ & $1(2)$ & 0.29 \\
\hline $\begin{array}{l}\text { Normal } \\
\text { development }\end{array}$ & $\begin{array}{l}71 \\
(96)\end{array}$ & $254(14-365)$ & & $16(94)$ & $8(89)$ & $45(98)$ & \\
\hline $\begin{array}{l}\geq 1 \text { hospitalization } \\
\text { (girls) }\end{array}$ & $\begin{array}{l}2 \\
(7)\end{array}$ & $365(56-365)$ & 0.90 & $0(0)$ & $0(0)$ & $2(10)$ & 1.00 \\
\hline $\begin{array}{l}\text { O hospitalizations } \\
\text { (girls) }\end{array}$ & $\begin{array}{l}28 \\
(93)\end{array}$ & $257(14-365)$ & & $6(100)$ & $3(100)$ & $18(90)$ & \\
\hline $\begin{array}{l}\geq 1 \text { hospitalization } \\
\text { (boys) }\end{array}$ & $\begin{array}{l}6 \\
(14)\end{array}$ & $229(137-365)$ & 0.92 & $1(9)$ & $2(33)$ & $3(12)$ & 0.44 \\
\hline $\begin{array}{l}0 \text { hospitalizations } \\
\text { (boys) }\end{array}$ & $\begin{array}{l}38 \\
(86)\end{array}$ & $216(44-365)$ & & $10(91)$ & $4(67)$ & $23(88)$ & \\
\hline $\begin{array}{l}\geq 1 \text { antibiotic use } \\
\text { (systemic) girls }\end{array}$ & $\begin{array}{l}7 \\
(23)\end{array}$ & $259(56-365)$ & 0.96 & $0(0)$ & $0(0)$ & $6(30)$ & 0.26 \\
\hline $\begin{array}{l}0 \text { antibiotic use } \\
\text { (systemic) girls }\end{array}$ & $\begin{array}{l}23 \\
(77)\end{array}$ & $254(14-365)$ & & $6(100)$ & $3(100)$ & $14(70)$ & \\
\hline $\begin{array}{l}\geq 1 \text { antibiotic use } \\
\text { (systemic) boys }\end{array}$ & $\begin{array}{l}8 \\
(18)\end{array}$ & $294(110-365)$ & 0.35 & $1(9)$ & $4(67)$ & $3(12)$ & 0.01 \\
\hline $\begin{array}{l}0 \text { antibiotic use } \\
\text { (systemic) boys }\end{array}$ & $\begin{array}{l}36 \\
(82)\end{array}$ & $214(44-365)$ & & $10(91)$ & $2(33)$ & $23(88)$ & \\
\hline
\end{tabular}

Abbreviations: IFN- $\beta$ = interferon-beta; GA = glatiramer acetate.

during pregnancy, nor between breastfeeding duration. The duration of IFN- $\beta /$ GA-exposed breastfeeding was similar among children with and those without adverse outcomes. Table 3 depicts crude and adjusted OR for adverse infant outcomes for the duration of exposed breastfeeding, the group exposed to IFN- $\beta$ or GA during pregnancy, and the exclusive breastfeeding group. Hospitalization and antibiotic use were considered for girls and boys together. Neither the duration of IFN- $\beta /$ GA-exposed breastfeeding nor 3rd trimester or longer IFN- $\beta /$ GA exposure increased the odds of hospitalization or systemic antibiotic use in the first year of life (table 3). Exclusively breastfed babies were less likely to be hospitalized or receive antibiotics after adjustment for other factors, but this did not reach statistical significance (table 3 ). Of interest, boys who received at least 1 course of systemic antibiotics were more likely to have been exposed to IFN$\beta /$ GA during the 3 rd trimester or longer $(\mathrm{n}=5[\mathrm{n}=1$ continuous and $n=42$ nd and/or 3rd trimester], 62.5\%) compared with those boys of our cohort without systemic antibiotic use $(\mathrm{n}=12,33.3 \%, p=0.01)$ (columns 5 and 6 of table 2). Analyses with the separate IFN- $\beta$ or GA subgroups showed no further statistical differences between either group and the reference populations.

\section{Discussion}

In our cohort, a broad array of infant outcomes in the first year of life did not seem to have been negatively influenced by maternal exposure to IFN- $\beta$ or GA during breastfeeding, although the sample size was too small to rule out rare adverse events. Physical growth curves lay within expected percentiles of the general German population. ${ }^{15}$ The observed percentage of children with developmental delay (4\%) was consistent with the general pediatric population $(5 \%-6 \%) .{ }^{17}$ Exposure to an immune modulator might raise concerns about an elevated occurrence of infections, but the percentage of infants with at least 1 systemic antibiotic treatment in the first year and the percentage of infants with at least 1 hospitalization we observed are consistent with the reference population. ${ }^{14,16}$

Data on early child development even independent of DMT exposure during pregnancy or breastfeeding in offspring of women with MS are scarce. Three studies with 1st trimester exposure of IFN- $\beta^{18,19}$ or GA $^{20}$ compared with unexposed ${ }^{19,20}$ found no increase in delay of reaching major milestones for both groups up to the age of $1^{18}$ and $2.1^{19,20}$ years, but $2^{18,19}$ reported lower birth weight. In 2 small $(n=21)$ case series with 
Table 3 Association IFN- $\beta$ or GA exposure through breastfeeding, in utero exposure, or exclusive breastfeeding and physical growth retardation, hospitalizations, or systemic antibiotic use in the first year of life

\begin{tabular}{|c|c|c|c|c|c|c|}
\hline & \multicolumn{2}{|c|}{ Duration of IFN- $\beta$ /GA-exposed breastfeeding } & \multicolumn{2}{|c|}{ In utero IFN- $\beta / G A$ exposure ${ }^{a}$} & \multicolumn{2}{|c|}{ Exclusive breastfeeding ${ }^{b}$} \\
\hline & OR $(95 \% \mathrm{CI})$ & $p$ Value & OR $(95 \% \mathrm{Cl})$ & $p$ Value & OR $(95 \% \mathrm{Cl})$ & $p$ Value \\
\hline \multicolumn{7}{|c|}{ Growth retardation } \\
\hline Crude OR & $1.00(1.00-1.01)$ & 0.27 & $1.50(0.31-7.36)$ & 0.62 & $2.00(0.22-17.98)$ & 0.54 \\
\hline Adjusted OR & $1.00(1.00-1.01)$ & 0.14 & $2.1(0.37-12.01)$ & 0.40 & $1.21(0.11-12.75)$ & 0.88 \\
\hline \multicolumn{7}{|c|}{$\geq 1$ hospitalization } \\
\hline Crude OR & $1.00(1.00-1.01)$ & 0.86 & $1.12(0.25-5.12)$ & 0.88 & $0.45(0.10-2.11)$ & 0.31 \\
\hline Adjusted OR & $1.00(1.00-1.01)$ & 0.39 & $1.74(0.32-9.42)$ & 0.52 & $0.33(0.06-1.87)$ & 0.21 \\
\hline \multicolumn{7}{|c|}{$\geq 1$ antibiotic use (systemic) } \\
\hline Crude OR & $1.00(1.00-1.00)$ & 0.81 & $0.91(0.27-3.00)$ & 0.87 & $0.51(0.15-1.78)$ & 0.29 \\
\hline Adjusted OR & $1.00(1.00-1.00)$ & 0.98 & $0.62(0.16-2.41)$ & 0.49 & $0.41(0.11-1.54)$ & 0.19 \\
\hline $\begin{array}{l}\text { Abbreviations: G } \\
\text { a Third trimester } \\
\text { b } \text { For at least } 2 \mathrm{~m}\end{array}$ & cetate; IFN- $\beta=$ inte & & & & & \\
\hline
\end{tabular}

GA ${ }^{6,7}$ and IFN- $\beta^{6}$ exposure throughout pregnancy and lactation, children developed normally up to the age of 1 year $^{7}$ and 6 months $^{6}$ apart from 1 child with inadequate language performance. ${ }^{7}$ Limitations were nonstandardized developmental follow-up ${ }^{6}$ and small case size. ${ }^{6,7}$

The observed lack of negative effects in breastfed children is biologically plausible because the drug amount of IFN- $\beta$ and GA in breast milk is expected to be very low ${ }^{8,21}$ and the oral bioavailability limited. ${ }^{9,10}$ The drug amount in breast milk depends on the combination of the drugs' molecular weight, maternal plasma levels, which are low for IFN- $\beta,{ }^{22}$ and other chemical properties. ${ }^{23-26}$ IFN- $\beta$ and GA are large molecules with average molecular weights of $20 \mathrm{kDa}^{9}$ and $5,000-9,000$ $\mathrm{Da},{ }^{21}$ respectively. Drugs larger than $800 \mathrm{Da}$ pass into breast

Table 4 Available data on body measurement

\begin{tabular}{lllll}
\hline \multirow{2}{*}{$\begin{array}{l}\text { Well-baby } \\
\text { visit }\end{array}$} & $\begin{array}{l}\text { Weight, } \\
\mathbf{n}(\%)\end{array}$ & $\begin{array}{l}\text { Length, } \\
\mathbf{n}(\%)\end{array}$ & $\begin{array}{l}\text { Head } \\
\text { circumference, } \mathbf{n}(\%)\end{array}$ \\
\hline Girl & & & \\
\hline & Birth & $28(100)$ & $28(100)$ & $27(96)$ \\
\hline 7 mo & $19(68)$ & $19(68)$ & $19(68)$ \\
\hline Boy & 12 mo & $25(89)$ & $25(89)$ & $25(89)$ \\
\hline & Birth & $39(100)$ & $39(100)$ & $34(87)$ \\
\hline 7 mo & $21(54)$ & $21(54)$ & $20(51)$ \\
\hline 12 mo & $34(87)$ & $34(87)$ & $34(87)$ \\
\hline
\end{tabular}

milk in at best trace amounts. ${ }^{23}$ In addition, low lipophilicity ${ }^{27}$ and high albumin binding ${ }^{28}$ further decrease the likelihood for GA to pass into breast milk.

Apart from the transfer into breast milk, the drug's oral absorption is crucial for an effect on the child. Drugs that are poorly orally absorbed like IFN- $\beta$ and GA are not likely to enter the child's blood system and cause pharmacologic effects. ${ }^{25}$ The poor oral bioavailability of proteins like IFN- $\beta$ and the synthetic polypeptide $\mathrm{GA}^{10}$ arises from denaturation and proteolytic degradation in the gastrointestinal tract. ${ }^{9}$ Perhaps the strongest evidence for poor oral bioavailability of IFN- $\beta$ and GA comes from randomized controlled trials of oral formulations in adults that showed no effect on MS disease activity. ${ }^{29,30}$

It is thus not surprising that in a case series of 6 women, IFN $\beta$-1a was detected in very low levels with a relative infant dose (RID) of $0.006 \%{ }^{8}$ in breast milk. The RID is used to assess the possible risk from a drug for a breastfed child. It is calculated by dividing the infant dose $(\mathrm{mg} / \mathrm{kg}$ per day) by the maternal dose in ( $\mathrm{mg} / \mathrm{kg}$ per day). RIDs of $<10 \%$ are considered probably safe for a healthy child. ${ }^{23}$ No data on GA excretion into human breast milk are available, owing most likely to technical difficulties in distinguishing it from naturally occurring peptides. ${ }^{27}$

The findings from this study are reassuring for women with MS who are afraid of staying untreated yet wish to breastfeed. Breast milk provides all nutritional and immunologic components a child needs to grow. ${ }^{31}$ Breastfeeding is associated with positive health outcomes for mother and child and recommended by the World Health Organization. ${ }^{32}$ Beside the instant transfer of maternal antibodies and protection from infections in the neonatal period-as seen in our cohort with fewer hospitalizations and antibiotic use in exclusively 
breastfed children-longer benefits could include protection from autoimmune diseases later in life. ${ }^{33}$ Maternal benefits include protective effects against breast $^{34}$ and ovarian cancer, ${ }^{34,35}$ type 2 diabetes, ${ }^{34}$ and rheumatoid arthritis. ${ }^{35}$ Suspected short-term maternal benefits of exclusive breastfeeding include a reduced risk of early postpartum relapses., ${ }^{3,4}$

Breastfeeding also appears to improve childhood cognitive performance. The National Longitudinal Study of Adolescent Health investigated 4,425 siblings and found a higher cognitive ability in breastfed children than in their nonbreastfed siblings. ${ }^{36}$ Even in children at high risk of cognitive impairment from in utero valproate exposure, breastfed children had higher intelligent quotients and verbal abilities compared with those who were not breastfed ${ }^{37}$ despite continued exposure to valproate through breast milk. These data indicate that forgoing breastfeeding should be recommended only if the mother needs a treatment where there is evidence or strong biological plausibility that it will adversely affect the breastfed infant.

The main limitation of our study is the overlap between IFN- $\beta$ /GA therapy during pregnancy and breastfeeding. Because most infants had at least some exposure during pregnancy in addition to breastfeeding, it precludes making precise conclusions about the safety of exposure through breast milk alone. However, this overlap would be expected to increase the risk of adverse events making our findings even more reassuring because we found no increased risk of adverse outcomes compared with the general population. As we captured only infections resulting in antibiotic use, we cannot determine differences regarding the number of uncomplicated infections. Another limitation is the relatively small sample size due to which only common (adverse) effects would have been observed. Rare negative effects cannot be excluded from present analysis, and more data have to be collected over time. Continued safety studies are recommended to address these limitations. Recall bias or overreporting is unlikely to affect our findings as we collect data prospectively and at short intervals. ${ }^{38} \mathrm{We}$ plan to proceed with follow-up of the children to capture potential behavioral abnormalities not detectable in the first year of life.

Strengths of this study include the importance of the question, the prospective follow-up, and the wide range of outcomes potentially influenced by exposure to immunologic medications studied.

Our findings, taken together with the lack of biological plausibility of adverse infant effects, indicate that it is overly conservative to recommend foregoing breastfeeding to continue or resume IFN- $\beta$ or GA. On the one hand it remains unclear whether rare negative effects on infants are to be expected or if continuing IFN- $\beta$ or GA through pregnancy or resuming DMTs in the early postpartum period reduces the risk of postpartum relapses. ${ }^{39}$ On the other hand there is strong evidence that recommending withholding the well- established infant and maternal health benefits of breastfeeding may be harmful. ${ }^{1}$ Our findings can help mothers and neurologists adopt a new perspective when considering IFN- $\beta$ or GA treatment during lactation. ${ }^{40}$

\section{Acknowledgment}

The authors thank all the participants of the DMSKW as well as the referring neurologists and MS nurses.

\section{Study funding}

The German Multiple Sclerosis and Pregnancy Registry (DMSKW) is partly supported by the Innovation Fund of the Federal Joint Committee, Bayer HealthCare Pharmaceuticals, Biogen, Teva Pharma, Novartis, and Merck.

\section{Disclosure}

A.I. Ciplea has received speaker honoraria from Bayer HealthCare and travel grants from Sanofi Genzyme, Teva, and Novartis. A. Langer-Gould and A. Stahl report no disclosures relevant to the manuscript. S. Thiel has received speaker honoraria from Bayer HealthCare. A. QueisserWahrendorf reports no disclosures relevant to the manuscript. R. Gold has received payments for consultancy from Biogen and Teva and speaker honoraria and research grants from Biogen Idec Germany, Teva, Sanofi-Aventis, Novartis, Bayer HealthCare and Merck Serono. K. Hellwig has received travel grants from Biogen, Novartis, and Merck and received speaker and research honoraria from Biogen Idec Germany, Teva, Sanofi Genzyme, Novartis, Bayer HealthCare, Merck Serono, and Roche. Go to Neurology.org/NN for full disclosures.

\section{Publication history}

Received by Neurology: Neuroimmunology \& Neuroinflammation November 4, 2019. Accepted in final form February 19, 2020.

\begin{tabular}{|c|c|c|}
\hline Name & Location & Contribution \\
\hline $\begin{array}{l}\text { Andrea Ines } \\
\text { Ciplea }\end{array}$ & $\begin{array}{l}\text { Department of } \\
\text { Neurology, St. Josef } \\
\text { Hospital, Ruhr- } \\
\text { University Bochum; } \\
\text { Institute of Clinical } \\
\text { Pharmacy and } \\
\text { Pharmacotherapy, } \\
\text { Heinrich-Heine- } \\
\text { University, Dusseldorf, } \\
\text { Germany }\end{array}$ & $\begin{array}{l}\text { Conception of the study, } \\
\text { acquisition of data, } \\
\text { drafting of the } \\
\text { manuscript, statistical } \\
\text { analysis, interpretation } \\
\text { of the data, and revision } \\
\text { of the manuscript for } \\
\text { intellectual content }\end{array}$ \\
\hline $\begin{array}{l}\text { Annette } \\
\text { Langer- } \\
\text { Gould, MD, } \\
\text { PhD }\end{array}$ & $\begin{array}{l}\text { Department of } \\
\text { Neurology, Southern } \\
\text { California Permanente } \\
\text { Medical Group/Kaiser } \\
\text { Permanente, Los } \\
\text { Angeles Medical Center }\end{array}$ & $\begin{array}{l}\text { Conception of the study } \\
\text { and revision of the } \\
\text { manuscript for } \\
\text { intellectual content }\end{array}$ \\
\hline $\begin{array}{l}\text { Anna Stahl, } \\
\text { MD }\end{array}$ & $\begin{array}{l}\text { Department of } \\
\text { Paediatrics, St. Josef } \\
\text { Hospital, Ruhr- } \\
\text { University Bochum, } \\
\text { Germany }\end{array}$ & $\begin{array}{l}\text { Acquisition of data and } \\
\text { revision of the } \\
\text { manuscript for } \\
\text { intellectual content }\end{array}$ \\
\hline
\end{tabular}


Appendix (continued)

\begin{tabular}{|c|c|c|}
\hline Name & Location & Contribution \\
\hline $\begin{array}{l}\text { Sandra Thiel, } \\
\text { PhD }\end{array}$ & $\begin{array}{l}\text { Department of } \\
\text { Neurology, St. Josef } \\
\text { Hospital, Ruhr- } \\
\text { University Bochum, } \\
\text { Germany }\end{array}$ & $\begin{array}{l}\text { Acquisition of data and } \\
\text { revision of the } \\
\text { manuscript for } \\
\text { intellectual content }\end{array}$ \\
\hline $\begin{array}{l}\text { Annette } \\
\text { Queisser- } \\
\text { Wahrendorf, } \\
\text { MD }\end{array}$ & $\begin{array}{l}\text { Centre of Paediatrics } \\
\text { and Youth Medicine, } \\
\text { Johannes Gutenberg } \\
\text { University of Mainz, } \\
\text { Germany }\end{array}$ & $\begin{array}{l}\text { Revision of the } \\
\text { manuscript for } \\
\text { intellectual content and } \\
\text { classification of } \\
\text { congenital anomalies }\end{array}$ \\
\hline Ralf Gold, MD & $\begin{array}{l}\text { Department of } \\
\text { Neurology, St. Josef } \\
\text { Hospital, Ruhr- } \\
\text { University Bochum, } \\
\text { Germany }\end{array}$ & $\begin{array}{l}\text { Revision of the } \\
\text { manuscript for } \\
\text { intellectual content }\end{array}$ \\
\hline $\begin{array}{l}\text { Kerstin } \\
\text { Hellwig, MD }\end{array}$ & $\begin{array}{l}\text { Department of } \\
\text { Neurology, St. Josef } \\
\text { Hospital, Ruhr- } \\
\text { University Bochum, } \\
\text { Germany }\end{array}$ & $\begin{array}{l}\text { Design and conception } \\
\text { of the study, statistical } \\
\text { analysis, interpretation } \\
\text { of the data, and revision } \\
\text { of the manuscript for } \\
\text { intellectual content }\end{array}$ \\
\hline
\end{tabular}

\section{References}

1. Victora CG, Bahl R, Barros AJ, et al. Breastfeeding in the 21st century: epidemiology, mechanisms, and lifelong effect. Lancet 2016;387:475-490.

2. Nelson LM, Franklin GM, Jones MC. Risk of multiple sclerosis exacerbation during pregnancy and breast-feeding. JAMA 1988;259:3441-3443.

3. Langer-Gould A, Huang SM, Gupta R, et al. Exclusive breastfeeding and the risk of postpartum relapses in women with multiple sclerosis. Arch Neurol 2009;66: 958-963.

4. Hellwig K, Rockhoff M, Herbstritt S, et al. Exclusive breastfeeding and the effect on postpartum multiple sclerosis relapses. JAMA Neurol 2015;72:1132-1138.

5. Portaccio E, Amato MP. Breastfeeding and post-partum relapses in multiple sclerosis patients. Mult Scler 2019;25:1211-1216.

6. Hellwig K, Gold R. Glatiramer acetate and interferon-beta throughout gestation and postpartum in women with multiple sclerosis. J Neurol 2011;258:502-503.

7. Fragoso YD, Finkelsztejn A, Kaimen-Maciel DR, et al. Long-term use of glatiramer acetate by 11 pregnant women with multiple sclerosis: a retrospective, multicentre case series. CNS drugs 2010;24:969-976.

8. Hale TW, Siddiqui AA, Baker TE. Transfer of interferon beta-1a into human breastmilk. Breastfeed Med 2012;7:123-125.

9. Hegen $\mathrm{H}$, Auer M, Deisenhammer F. Pharmacokinetic considerations in the treatment of multiple sclerosis with interferon-beta. Expert Opin Drug Metab Toxicol 2015;11:1803-1819.

10. Messina S, Patti F. The pharmacokinetics of glatiramer acetate for multiple sclerosis treatment. Expert Opin Drug Metab Toxicol 2013;9:1349-1359.

11. Herbstritt S, Langer-Gould A, Rockhoff $M$, et al. Glatiramer acetate during early pregnancy: a prospective cohort study. Mult Scler 2016;22:810-816.

12. Uphoff R, Nather A. Das neur Gelbe Kinderuntersuchungsheft [in German]. Kinderkrankenschwester 2016;35:384-385.

13. Schmidtke C, Kuntz B, Starker A, Lampert T. Inanspruchnahme der Früherkennungsuntersuchungen für Kinder in Deutschland - Querschnittergebnisse aus KiGGS Welle 2 [in German]. J Health Monit 2018;3.

14. Greiner W, Batram M, Scholz S, Witte J. Kinder- und Jugendreport NordrheinWestfalen Gesundheitsversorgung von Kindern- und Jugendlichen in Nordrhein-
Westfalen. 2019. Available at: www.dak.de/dak/download/download-kinder-undjugendreport-2019-nordrhein-westfalen-2106266.pdf. Accessed January 13, 2020.

15. Neuhauser H, Schienkiewitz A, Schaffrath Rosario A, Dortschy R, Kurth BM. Referenzperzentile für anthropometrische Maßzahlen und Blutdruck aus der Studie zur Gesundheit von Kindern und Jugendlichen in Deutschland (KiGGS). 2013;2. erweiterte Auflage. Available at: www.rki.de/DE/Content/Gesundheitsmonitoring/ Gesundheitsberichterstattung/GBEDownloadsB/KiGGS_Referenzperzentile.html. Accessed January 13, 2020.

16. Greiner W, Batram M, Scholz S. Kinder- und Jugendreport 2018 Schleswig Holstein. 2018. Available at: www.dak.de/dak/download/report-2106236.pdf. Accessed January $13,2020$.

17. Deutsch-Schweizerische Versorgungsleitlinie basierend auf internationalen Empfehlungen (EACD-Consensus) zu Definition, Diagnose, Untersuchung und Behandlung bei Umschriebenen Entwicklungsstörungen motorischer Funktionen (UEMF). 2011. Available at: www.awmf.org/leitlinien/detail/II/022-017.html. Accessed January 13, 2020.

18. Patti F, Cavallaro T, Lo Fermo S, et al. Is in utero early-exposure to interferon beta a risk factor for pregnancy outcomes in multiple sclerosis? J Neurol 2008;255: $1250-1253$.

19. Amato MP, Portaccio E, Ghezzi A, et al. Pregnancy and fetal outcomes after interferon-beta exposure in multiple sclerosis. Neurology 2010;75:1794-1802.

20. Giannini M, Portaccio E, Ghezzi A, et al. Pregnancy and fetal outcomes after glatiramer acetate exposure in patients with multiple sclerosis: a prospective observational multicentric study. BMC Neurol 2012;12:124.

21. Alhakamy NA, Berkland CJ. Glatiramer acetate (copaxone) is a promising gene delivery vector. Mol Pharm 2019;16:1596-1605.

22. EMA. Betaferon (Interferon beta $1 \mathrm{~b}$ ) EPAR Summary of Product characteristics. Available at: www.ema.europa.eu/en/documents/product-information/betaferonepar-product-information_en.pdf. Accessed January 13, 2020.

23. Newton ER, Hale TW. Drugs in breast milk. Clin Obstet Gynecol 2015;58:868-884.

24. Gardiner S. E B. Drug Safety in Lactation. Prescriber Update. 2001;21:10-23. medsafe.govt.nz/Profs/PUarticles/lactation.htm. Accessed January 13, 2020.

25. Rowe H, Baker T, Hale TW. Maternal medication, drug use, and breastfeeding. Pediatr Clin North Am 2013;60:275-294.

26. Medicine Use in Lactation. Prescriber Update. 2015;36:22-25. medsafe.govt.nz/ Profs/PUarticles/June2015/June2015Lactation.htm. Accessed January 13, 2020.

27. Neuhaus O, Kieseier BC, Hartung HP. Pharmacokinetics and pharmacodynamics of the interferon-betas, glatiramer acetate, and mitoxantrone in multiple sclerosis. J Neurol Sci 2007;259:27-37.

28. Anderson PO, Sauberan JB. Modeling drug passage into human milk. Clin Pharmacol Ther 2016;100:42-52.

29. Polman C, Barkhof F, Kappos L, et al. Oral interferon beta-1a in relapsing-remitting multiple sclerosis: a double-blind randomized study. Mult Scler 2003;9:342-348.

30. Filippi M, Wolinsky JS, Comi G. Effects of oral glatiramer acetate on clinical and MRImonitored disease activity in patients with relapsing multiple sclerosis: a multicentre, double-blind, randomised, placebo-controlled study. Lancet Neurol 2006;5:213-220.

31. Ballard O, Morrow AL. Human milk composition: nutrients and bioactive factors. Pediatr Clin North Am 2013;60:49-74.

32. WHO, UNICEF. Global Strategy for Infant and Young Child Feeding. Geneva, Switzerland: World Health Organization; 2003.

33. Jackson KM, Nazar AM. Breastfeeding, the immune response, and long-term health. J Am Osteopath Assoc 2006;106:203-207.

34. Chowdhury R, Sinha B, Sankar MJ, et al. Breastfeeding and maternal health outcomes: a systematic review and meta-analysis. Acta Paediatr 2015;104:96-113.

35. Allen J, Hector D. Benefits of breastfeeding. N S W Public Health Bull 2005; 16:42-46.

36. Evenhouse E, Reilly S. Improved estimates of the benefits of breastfeeding using sibling comparisons to reduce selection bias. Health Serv Res 2005;40(6 pt 1): 1781-1802.

37. Meador KJ, Baker GA, Browning N, et al. Breastfeeding in children of women taking antiepileptic drugs: cognitive outcomes at age 6 years. JAMA Pediatr 2014;168: 729-736.

38. Infante-Rivard C, Jacques L. Empirical study of parental recall bias. Am J Epidemiol 2000;152:480-486.

39. Portaccio E, Amato MP. Breastfeeding and post-partum relapses in multiple sclerosis patients. Mult Scler 2019;25:1211-1216.

40. Langer-Gould AM. Pregnancy and family planning in multiple sclerosis. Continuum (Minneap Minn) 2019;25:773-792. 


\title{
Neurology \\ Neuroimmunology \& Neuroinflammation
}

\author{
Safety of potential breast milk exposure to IFN- $\beta$ or glatiramer acetate: One-year \\ infant outcomes \\ Andrea Ines Ciplea, Annette Langer-Gould, Anna Stahl, et al. \\ Neurol Neuroimmunol Neuroinflamm 2020;7; \\ DOI 10.1212/NXI.0000000000000757
}

This information is current as of May 20, 2020

\section{Updated Information \& \\ Services}

References

Citations

Subspecialty Collections

Permissions \& Licensing

Reprints including high resolution figures, can be found at:

http://nn.neurology.org/content/7/4/e757.full.html

This article cites 31 articles, 0 of which you can access for free at: http://nn.neurology.org/content/7/4/e757.full.html\#\#ref-list-1

This article has been cited by 1 HighWire-hosted articles: http://nn.neurology.org/content/7/4/e757.full.html\#\#otherarticles

This article, along with others on similar topics, appears in the following collection(s):

Cohort studies

http://nn.neurology.org//cgi/collection/cohort_studies

Multiple sclerosis

http://nn.neurology.org//cgi/collection/multiple_sclerosis

Information about reproducing this article in parts (figures,tables) or in its entirety can be found online at:

http://nn.neurology.org/misc/about.xhtml\#permissions

Information about ordering reprints can be found online:

http://nn.neurology.org/misc/addir.xhtml\#reprintsus

Neurol Neuroimmunol Neuroinflamm is an official journal of the American Academy of Neurology.

Published since April 2014, it is an open-access, online-only, continuous publication journal. Copyright

Copyright (C) 2020 The Author(s). Published by Wolters Kluwer Health, Inc. on behalf of the American

Academy of Neurology.. All rights reserved. Online ISSN: 2332-7812.

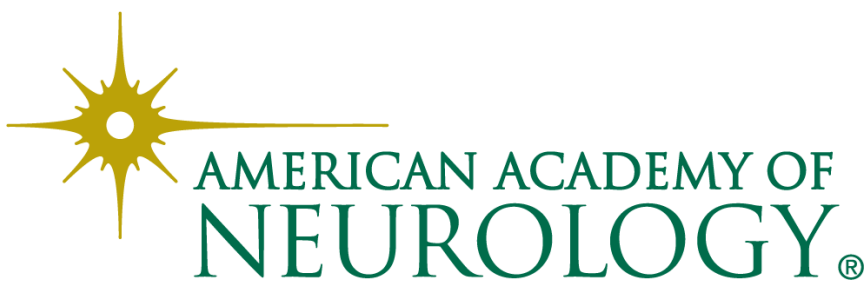

